\title{
INTESTINAL ISCHEMIA/REPERFUSION INDUCES BRONCHIAL HYPERREACTIVITY AND INCREASES SERUM TNF- $\alpha$ IN RATS
}

Marcio Jose Cristiano de Arruda, Renato Sergio Poggetti, Belchor Fontes, Riad N.Younes, Almerindo Lourenço Souza Jr., and Dario Birolini

\begin{abstract}
Arruda MJC de, Poggetti RS, Fontes B, Younes RN, Souza Jr. AL, Birolini D. Intestinal ischemia/reperfusion induces
\end{abstract} bronchial hyperreactivity and increases serum TNF- $\alpha$ in rats. Clinics. 2006;61(1):21-8.

INTRODUCTION: Intestinal or hepatic ischemia/reperfusion induces acute lung injury in animal models of multiple organ failure. Tumor necrosis factor (TNF)- $\alpha$ is involved in the underlying inflammatory mechanism of acute respiratory distress syndrome. Although the inflammatory cascade leading to acute respiratory distress syndrome has been extensively investigated, the mechanical components of acute respiratory distress syndrome are not fully understood. Our hypothesis is that splanchnic ischemia/reperfusion increases airway reactivity and serum TNF- $\alpha$ levels.

OBJECTIVE: To assess bronchial smooth muscle reactivity under methacholine stimulation, and to measure serum TNF- $\alpha$ levels following intestinal and/or hepatic ischemia/reperfusion in rats.

METHOD: Rats were subjected to 45 minutes of intestinal ischemia, or 20 minutes of hepatic ischemia, or to both (double ischemia), or sham procedures (control), followed by 120 minutes of reperfusion. The animals were then sacrificed, and the bronchial response to increasing methacholine molar concentrations $\left(10^{-7}\right.$ to $\left.3 \times 10^{-4}\right)$ was evaluated in an ex-vivo bronchial muscle preparation. Serum TNF- $\alpha$ was determined by the L929-cell bioassay.

RESULTS: Bronchial response ( $\mathrm{g} / 100 \mathrm{mg}$ tissue) showed increased reactivity to increasing methacholine concentrations in the intestinal ischemia and double ischemia groups, but not in the hepatic ischemia group. Similarly, serum TNF- $\alpha$ (pg/mL) concentration was increased in the intestinal ischemia and double ischemia groups, but not in the hepatic ischemia group.

CONCLUSION: Intestinal ischemia, either isolated or associated with hepatic ischemia, increased bronchial smooth muscle reactivity, suggesting a possible role for bronchial constriction in respiratory dysfunction following splanchnic ischemia/reperfusion. This increase occurred in concomitance with serum TNF- $\alpha$ increase, but whether the increase in TNF- $\alpha$ caused this bronchial contractility remains to be determined.

KEYWORDS: Mechanical factor of ARDS. Bronchial contractility. Intestinal and hepatic ischemia.

\section{INTRODUCTION}

Despite recent improvements in trauma care, acute respiratory distress syndrome (ARDS) remains a common complication in trauma patients sustaining severe hemorrhagic shock. ARDS contributes to the multiple or-

Laboratory of Medical Investigation (LIM-62) of the Emergency Surgery Service, Hospital das Clinicas, São Paulo University Medical School - São Paulo/SP, Brazil.

E-mail: belchor@uol.com.br

Received for publication on August 02, 2005.

Accepted for publication on November 11, 2005. gan dysfunction syndrome (MODS), which is the leading cause of death in these patients. ${ }^{1}$ Although continually under investigation, the mechanisms of ARDS and MODS are still not fully understood. Most studies focus on the inflammatory component of these syndromes. ${ }^{2,3}$ However, some clinical observations have shown that ARDS patients have mechanical respiratory disturbances, basically decreased pulmonary compliance and increased airway resistance, ${ }^{4-6}$ suggesting that a mechanical component may have a role in the underlying mechanism of this syndrome.

Hemorrhagic shock, frequently associated with impaired mesenteric blood flow and tissue ischemia, is a common 
event in trauma patients. ${ }^{7}$ The successful management of shock with aggressive fluid replacement restores tissue reperfusion, but may be followed by the systemic inflammatory response syndrome (SIRS) and reperfusion injury to the lung (acute lung injury - ALI) and other organs, leading to ARDS and MODS. ${ }^{8-11}$ It has been shown that after 45 minutes of intestinal ischemia (II) followed by $2 \mathrm{hrs}$ of reperfusion, acute lung injury (ALI) is observed, with increased lung vascular permeability and lung neutrophil sequestration. ${ }^{12-17}$

Using this model, it has more recently been shown in our laboratory that, after 60 minutes of reperfusion, lung macrophages are activated, with significant TNF- $\alpha$ and $\mathrm{H}_{2} \mathrm{O}_{2}$ production. ${ }^{18}$ Besides its well-known action as inflammatory mediator, TNF- $\alpha$ has been suggested as a possible mediator of airway hyperreactivity, although the mechanism for this action is still not clear. ${ }^{19-21}$

The surgical control of bleeding liver injuries in trauma patients with hemorrhagic shock usually requires special maneuvers, ${ }^{22-23}$ such as temporary clamping of the hepatic pedicle (Pringle's maneuver), ${ }^{24}$ resulting in HI followed by reperfusion (hepatic I/R). Hepatic I/R leads to the release of inflammatory mediators and may result in the development of ARDS and MODS. ${ }^{16,25}$ Thus, liver I/R and intestinal I/R are commonly associated events in patients sustaining liver injury and hemorrhagic shock. However, the associated effect of intestinal I/R and liver I/R on the development of ARDS and MODS has not been clearly established.

Based on clinical observation, the 20-minute period of $\mathrm{HI}$ resulting from Pringle's maneuver was traditionally accepted as a safe procedure for the patient, although without solid support from histology or laboratory investigation. ${ }^{27}$ More recently, total hepatic pedicle clamping for 30 minutes has been employed in trauma patients sustaining severe liver injuries. ${ }^{28}$ It has also been shown in rat models that $\mathrm{HI}$ followed by reperfusion is associated with increased serum levels of TNF. ${ }^{29}$ However, given the diversity of TNF actions in the mechanism of inflammatory response, the real role of TNF in the mechanism of lung and liver injury following II or $\mathrm{HI}$ has not been clearly determined. Furthermore, the effect of intestinal I/R and liver $\mathrm{I} / \mathrm{R}$ on the possible mechanical component of ARDS has not been reported.

Our hypothesis was that splanchnic ischemia/ reperfusion induces increased airway reactivity and increased serum levels of TNF- $\alpha$. Therefore, the objective of this study was to assess bronchial smooth muscle reactivity as well as serum TNF- $\alpha$ levels after intestinal and/ or HI followed by reperfusion in rats.

\section{MATERIALS AND METHODS}

Wistar male rats (290-390 g) from the animal facility of the University of São Paulo School of Medicine were employed throughout the experiments. All animals received humane care in compliance with the NIH Guide For Care And Use Of Laboratory Animals, publication 85-23, revised 1985. The study protocol was approved by the Institutional Ethics Committee for animal use in research studies. All surgical procedures were performed under general anesthesia with chloral hydrate $(400 \mathrm{mg} / \mathrm{kg}$, i.p.). Anesthetized animals were randomized into 4 groups as follows: 1) Control group ( $\mathrm{n}=11)$ : sham procedure; 2$) \mathrm{In}$ testinal ischemia (II) group $(n=7)$ : 45 minutes superior mesenteric artery occlusion; 3) Hepatic ischemia (HI) group $(\mathrm{n}=8)$ : 20 minutes of hepatic pedicle clamping; 4) Double ischemia (DI) group: concomitant II and HI $(\mathrm{n}=8)$.

In the control group, a median laparotomy was performed, the superior mesenteric artery (SMA) and the hepatic pedicle were gently exposed, and the animals were observed for a time period equivalent to that of ischemia in the corresponding experimental (II, DI, HI) groups. During this period the laparotomy incision was covered with a plastic wrap to prevent fluid loss. The laparotomy incision was then closed with monofilament running suture, and the animals were observed during the following $120 \mathrm{~min}-$ utes corresponding to the reperfusion period of the other 3 groups. For intestinal I/R, the same procedures as in the control group were performed, except that at the end of vascular exposure, the superior mesentery artery was occluded with a vascular clamp (Vascu-statt no. 1001-531, Scalan International, Minn. 55107, USA) for 45 minutes. For liver ischemia, the hepatic pedicle was occluded with a clamp for 20 minutes; in the DI group, this clamp was applied at 25 minutes of the II period, and removed at the end of the 45 minutes of II. At the end of the ischemia, the clamp on the SMA and on the hepatic pedicle were removed, and the laparotomy incision was closed as in the control group. The time period of reperfusion was 120 minutes in all groups. A pilot study (data not shown) indicated that 45 minutes of II combined with 30 minutes of HI (initiated after 15 minutes of II) resulted in a mortality rate of $30 \%$ within 72 hours following the end ischemia; therefore, the period of HI was reduced to 20 minutes (beginning after 25 minutes of II), and no death occurred.

\section{Set-up of the isolated intrapulmonary bronchial segment.}

At the end of reperfusion, a median thoracotomy was performed, and the left intrapulmonary bronchial segment was removed and dissected free of connective tissue. The 
bronchial segment was suspended on 2 steel hooks in an 8-mL organ bath containing Krebs-Henseleit buffer solution aerated with $95 \% \mathrm{O}_{2}$ and $5 \% \mathrm{CO}_{2}$ and maintained at $36.5^{\circ} \mathrm{C}$. Isometric contractions were evaluated using a Narco F60 force displacement transducer connected to a Physiograph MKIII recorder. The intrapulmonary bronchial segment was allowed to equilibrate for 60 minutes under an initial tension of $500 \mathrm{mg}$. During this period, the bathing medium was replaced every 20 minutes. After equilibration, the tension was adjusted to the optimal length-active tension ( $1 \mathrm{~g}$ ). The tissue viability of the bronchial segment was assessed by the contraction-eliciting procedure, in which the contraction of the viable bronchial segment is elicited by replacing the Krebs buffer solution with isoosmolar Krebs-bicarbonate solution containing $60 \mathrm{mM}$ $\mathrm{KCl} .^{30,31}$

\section{Dose response curve to methacholine}

Once the tissue viability was determined, the organ bath fluid was refilled with Krebs solution, and the dose response curve was determined to methacholine, a muscarinic agonist commonly used in experimental models of bronchial contractility. ${ }^{31}$ For this purpose, isolated increasing doses of methacholine $\left(10^{-7}\right.$ to $10^{-3}$ molar) were added to the organ bath, and the force developed by the bronchial segment was recorded. The contractile effect of each dose of methacholine was observed until the maximum effect was reached ( 20 seconds to 2 minutes after the drug addition).

\section{Quantitation of serum TNF- $\alpha$ activity.}

At the end of reperfusion, blood samples were drawn from the heart by needle punction. The samples were kept on ice for 30 minutes for clot retraction, centrifuged at $1,620 \mathrm{~g}$ for 15 minutes, and the serum harvested for TNF$\alpha$ activity quantitation. TNF- $\alpha$ activity was measured by cytotoxicity assay using L-929 tumor cells. ${ }^{32}$ Briefly, $50 \mathrm{~mL}$ of serum was pipetted into 96-well microtiter plates containing target L-929 cells $\left(5 \times 10^{4}\right.$ cells $\left./ 50 \mathrm{~mL}\right)$ in the presence of actinomycin $\mathrm{D}$ (final concentration $5 \mathrm{mg} / \mathrm{mL}$ ). The cells were incubated with rat serum samples for $24 \mathrm{~h}$ at $37^{\circ} \mathrm{C}$. The supernatant was then discarded, and adherent cells were washed with PBS and stained with crystal violet for 15 minutes. The absorbance of the samples was read at $620 \mathrm{~nm}$ (ELISA Titertek Multiskam). TNF- $\alpha$ concentration (units $/ \mathrm{mL}$ ) was defined as the reciprocal of the dilution that induced $50 \%$ lysis of L-929 cells. In standard curves, $50 \%$ cytotoxicity was obtained with a dose of 9.2 pg recombinant rat TNF- $\alpha$.

\section{Statistics}

Data are presented as mean \pm SEM. The studied variables were compared using the fixed factor analysis of variance (ANOVA) F test. When a significant result was obtained using this test, the differences were identified by means of the multiple comparisons Scheffe test. Data normality was analyzed using the Shapiro-Silks test. Nonparametric tests were employed for the analysis of data presenting great variability, where the supposition of normality was not fulfilled. For comparison of groups as to these variables, the Kruskal-Wallis $(\mathrm{H})$ test for independent variables was employed. Differences with a $P<.05$ were considered statistically significant and denoted with an asterisk $(*)$

\section{RESULTS}

\section{Bronchial contractility}

Comparison of bronchial response to different levels of methacholine stimuli in the 4 groups (II, HI, DI, and control) is shown in Figure 1. For concentrations of $10^{-7}$ to $3 \mathrm{x}$ $10^{-7}$ molar methacholine, there was no difference between experimental and control groups. For methacholine concentrations from $10^{-5}$ to $3 \times 10^{-4}$ molar, intestinal ischemia provoked significantly increased bronchial contractility when compared to results of the control group. Bronchial contractility of the HI group was not different from that of the control group. However, in the DI group, the bronchial contractility was significantly different from that of the control group at methacholine concentrations starting at $3 \mathrm{x}$ $10^{-7}$ molar.

\section{Serum TNF- $\alpha$}

Serum TNF- $\alpha$ levels in the II $(631 \pm 185 \mathrm{pg} / \mathrm{mL})$ and DI $(539 \pm 121 \mathrm{pg} / \mathrm{mL})$ groups were significantly higher compared to TNF- $\alpha$ levels in the HI $(118 \pm 43 \mathrm{pg} / \mathrm{mL})$ and control $(54 \pm 31 \mathrm{pg} / \mathrm{mL})$ groups (Figure 2).

\section{DISCUSSION}

Clinical observations in ARDS patients have shown increased airway resistance to air flow and have suggested a therapeutic effect for the use of beta-agonist (metaproterenol) and salbutamol inhalation. ${ }^{33,34}$ Experimental and clinical investigations on the mechanism of ARDS have been mostly focused on the role of cellular and humoral mediators of the underlying inflammatory response, and they have further suggested a possible role for humoral 




Legend: Animal preparation: anesthesia + laparotomy + superior mesenteric artery (SMA) and hepatic pedicle (HP) identification

Figure 1 - Diagram: Main steps of the experiment

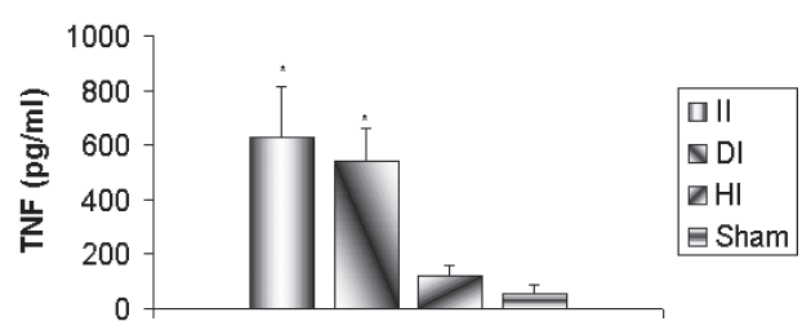

$\mathrm{II}=$ intestinal ischemia; $\mathrm{DI}=$ double (intestinal and hepatic) ischemia; $\mathrm{HI}=$ hepatic ischemia; Sham = control group; $*=p<0.05$ compared with Sham.

Figure 2 - Serum concentrations of TNF-a after intestinal and/or hepatic ischemia

inflammatory mediators, more specifically TNF- $\alpha$, in the increased bronchial reactivity. ${ }^{19,35-38}$ It has been shown, for instance, that animals treated with TNF- $\alpha$ inhalation presented increased airway resistance, and that pretreatment with a TNF- $\alpha$ receptor antagonist reversed this response. ${ }^{19,38}$ However, the actual role of increased bronchial reactivity in the mechanism of ARDS remains to be elucidated. The experimental models of intestinal ischemia (II) or hepatic ischemia (HI) have been largely employed to investigate the mechanism of acute lung injury, mimicking what happens in ARDS trauma patients..$^{14,25,26}$

In the present study, using a rat model of ischemia/ reperfusion (I/R), we investigated the mechanical component of $I / R$ on acute lung injury (ALI) in response to II and HI provoked either simultaneously or separately. This investigation was carried out by assessing serum TNF- $\alpha$ levels, as well as the response of airway smooth muscle to cholinergic stimuli, using a dose-response curve with 8 different molar concentrations $\left(10^{-7}\right.$ to $3 \times 10^{-4}$ molar) of methacholine. In an attempt to use a nonlethal stimulus that provokes acute lung injury, we adopted 45 minutes of II and 20 minutes of HI, followed by 120 minutes of reperfusion to both organ territories. Metabolic or hemodynamic evaluation was not included in this study, since it would have required animal manipulation for blood vessel catheterization and blood sampling, with potential adverse influences on the results.

The reason for the choice of the experimental model of simultaneous 45 minutes of II and 20 minutes of HI in the present study was that we were seeking a nonlethal rat model of combined II and HI leading to lung and liver injury. Thus, the model with 45 minutes of isolated II was chosen because it has been frequently used, and it has been shown to provoke lung and liver injury that is detectable at 6 hours of reperfusion and is reversible at 18 hours, with no mortality. $3,15,39-41$

Concerning the HI provoked by hepatic pedicle clamping, different ischemia periods have been previously reported, with mortality rates not clearly established. For instance, while some investigators have reported no mortality for an HI period of 30 minutes ${ }^{42}$ or for periods shorter than 45 minutes, ${ }^{43}$ a $9 \%$ mortality after 30 minutes of HI was reported by others. ${ }^{44}$ Additionally, a reversible increase in serum TNF- $\alpha$ levels was observed after 30 minutes of hepatic pedicle occlusion followed by 120 minutes reperfusion, with no mortality in rats. ${ }^{42}$ In a pilot study of 45 minutes of II combined with 30 minutes of HI, we ob- 
served a $30 \%$ mortality rate within 72 hours of reperfusion, whereas no death occurred when the HI period was reduced to 20 minutes. On the other hand, 20 minutes of total hepatic pedicle occlusion provoked increased intercellular spaces, decreased cytoplasm glycogen, and the presence of membrane vesicles in the cytoplasm of rat hepatocytes, suggesting that 20 minutes of $\mathrm{HI}$ is not an innocuous stimulus (Poggetti RS, unpublished data). Therefore, we used the combined model of 45 minutes II with 20 minutes $\mathrm{HI}$ in the present study.

In this study, we found that the animals subjected to intestinal ischemia presented a significant increase in bronchial reactivity to the 4 highest doses of methacholine used. Also in the animals subjected to double (intestinal and hepatic) ischemia, a significant increase in bronchial reactivity was observed. However, in the animals subjected to isolated HI, the bronchial response to methacholine was not different from that observed in the control animals. Furthermore, our results also show that the serum TNF- $\alpha$ concentration was significantly increased in the animals subjected to II, as well as to double ischemia, but not in the animals subjected to isolated HI, compared to control animals. Considering that a nonlethal stimulus (45 min of II and $20 \mathrm{~min}$ of $\mathrm{HI}$ ) was employed in this study and that $\mathrm{HI}$ (either isolated and/or combined with II) did not add a significant increase to the bronchial response to methacholine or to TNF- $\alpha$ release, this finding indicates that 20 minutes of HI may be an insufficient stimulus for either TNF- $\alpha$ production or bronchial contractility.

It should also be considered that, in addition to lung injury, the 45 minutes of II followed by 120 minutes reperfusion also provokes liver injury. ${ }^{15}$ The potential impact of this hepatic injury on the effects of HI was not considered in the present study. Other studies with longer periods of HI, either isolated or combined with II, might help to clarify whether HI may stimulate bronchial contractility and $\mathrm{TNF}-\alpha$ release. In this context, it may be noted that other similar situations have been studied, as for instance the effects of allopurinol and streptokinase, which have been shown to affect the outcome of lower limb ischemia/ reperfusion in rats $^{45}$.

Studying the direct effect of $\mathrm{TNF}-\alpha$ on pig tracheal smooth muscle, Pennings et al found increased contractile reactivity to cholinergic stimuli and showed that the use of soluble TNF- $\alpha$ receptors abolished these effects. ${ }^{38}$ This TNF- $\alpha$ action may be explained by the fact that TNF- $\alpha$, like other cytokines, is capable of altering the expression of prejunctional M2 subtype muscarinic receptors; these receptors are responsible for the negative feedback regulation of acetylcholine release at the synaptic cleft. At the intracellular level, TNF- $\alpha$ can stimulate the production of transcription factors that impair the production of these muscarinic receptors. ${ }^{46,47}$ It has been also shown that TNF$\alpha$ increases $\mathrm{G}$-protein affinity for M2-muscarinic receptors on rabbit airway smooth muscles, leading to a decreased smooth muscle relaxation in the presence of $\alpha$-adrenergic stimuli. $^{37,48}$

In conclusion, our finding that intestinal I/R provokes bronchial smooth muscle hyperreactivity in response to methacholine seems support the hypothesis that the respiratory dysfunction resulting from splanchnic ischemia has a mechanical component involving bronchial constriction. The findings of a simultaneous increase in serum TNF- $\alpha$ levels and bronchial hyperreactivity after intestinal I/R warrant further study to clarify the possible role of TNF- $\alpha$ in this phenomenon. Our results suggest also that HI of 20 minutes duration may be an insufficient stimulus to induce bronchial constriction or TNF- $\alpha$ release. Further studies are warranted to determine the possible role of hepatic ischemia in bronchial hyperreactivity.

\section{RESUMO}

Arruda MJC de, Poggetti RS, Fontes B, Younes RN, Souza Jr. AL, Birolini D. A isquemia/reperfusão intestinal provoca hiper-reatividade brônquica e aumento do TNF- $\alpha$ sérico em ratos. Clinics. 2006;61(1):21-8.
INTRODUCÃO: A isquemia/reperfusão intestinal ou hepática induz lesão pulmonar aguda em modelos animais de falência de múltiplos órgãos. $\mathrm{O}$ fator de necrose tumoral (TNF- $\alpha$ ) está envolvido no mecanismo inflamatório da 
síndrome da angústia respiratória aguda. Embora a cascata inflamatória que leva à síndrome da angústia respiratória aguda tenha sido extensamente investigada, os componentes mecânicos desta ainda não são completamente compreendidos. Nós levantamos a hipótese de que a isquemia/ reperfusão esplâncnica provoca aumento da reatividade contráctil das vias aéreas, bem como aumento do TNF- $\alpha$ sérico.

OBJETIVO: avaliar a reatividade da musculatura lisa brônquica sob estimulação com metacolina, e medir os níveis séricos de TNF- $\alpha$ após isquemia/reperfusão intestinal e/ou hepática em ratos.

MÉTODO: Ratos Wistar foram submetidos a $45 \mathrm{~min}$ de isquemia intestinal, ou 20 minutos de isquemia hepática, ou a ambas (isquemia dupla), ou controle, seguidos por 120 min de reperfusão. A resposta brônquica a concentrações molares $\left(10^{-7}\right.$ to $\left.3 \times 10^{-4}\right)$ de metacolina foi avaliada usandose uma preparação ex-vivo de musculatura brônquica.
RESULTADOS: A resposta brônquica (g/100mg de tecido) mostrou reatividade aumentada a concentrações crescentes de metacolina na isquemia intestinal e isquemia dupla, mas não na isquemia hepática. Similarmente, o TNF- $\alpha$ sérico aumentou na isquemia intestinal e isquemia dupla, mas não na isquemia hepática.

CONCLUSÃO: Isquemia intestinal, quer isolada ou associada à hepática, provocou hiper-reatividade da musculatura brônquica, sugerindo um possível papel da constrição brônquica na disfunção respiratória conseqüiente à isquemia/reperfusão esplâncnica. Este aumento foi simultâneo ao do TNF- $\alpha$ sérico, porém o possível efeito causal do TNF- $\alpha$ na contractilidade brônquica permanece a ser determinado.

UNITERMOS: SARA. Contractilidade brônquica. Isquemia intestinal e hepática.

\section{REFFERENCES}

1. Jacobs BB, Jacobs LM. Epidemiology of trauma. In: Feliciano DV, Moore EE, Mattox KL, editors. Trauma. 3rd ed. Stamford-Connecticut. Appleton \& Lange. 1996. p. 15-30.

2. Schmeling DJ, Caty MG, Oldham KT, Guice KS, Hinshaw DB. Evidence for neutrophil-related acute lung injury after intestinal ischemiareperfusion. Surgery. 1989;106:195-202.

3. Koike K, Moore EE, Moore FA, Read RA, Carl VS, Banerjee A. Gut schemia/reperfusion produces lung injury independent of endotoxin. Crit Care Med. 1994;22:1438-44.
4. Wright PE, Bernard GR. The role of airway resistence in patients with the adult respiratory distress syndrome. Am Rev Respir Dis. 1989;139:1169-74.

5. Broseghini C, Brandolese R, Poggi R, Polese G, Manzin E, Milic-Emili $\mathrm{J}$, et al. Respiratory mechanics during the first day of mechanical ventilation in patients with pulmonary edema and chronic airway obstruction. Am Rev Respir Dis. 1988;138:355-61.

6. Eissa NT, Ranieri VM, Corbeil C, Chasse M, Robatto FM, Braidy J, et al. Analysis of behavior of respiratory system in ARDS patients: effects of flow, volume, and time. J Appl Physiol. 1991;70:2719-29. 
7. Fiddian-Green RG. Hypotension, splanchnic hypoxia and arterial acidosis in ICU patients. Circ Shock. 1987;112:326.

8. Reilly PM, Shiller HJ, Bulkely GM. Reactive oxygen metabolites in shock. In: Wilmore DW, Brenan MF, Harken AH, editors. Early care of the surgical patient. Scientific American Inc. New York 1992. p. 325-8.

9. Moore FA, Moore EE. Evolving concepts in the pathogenesis of postinjury multiple organ failure. Surg Clin North Am. 1995;75:257-77.

10. Rocha-e-Silva M, Poli de Figueiredo LF. Small volume hypertonic resuscitation of circulatory shock. Clinics. 2005;60:159-172.

11. Turnage RH, Guice KS, Oldham KT. The effects of hypovolemia on multiple organ injury following intestinal reperfusion. Shock. 1994;1:408-13

12. Moore EE, Moore FA, Francoise RJ, Kim FJ, Biffl WL, Banerjee A. The postischemic gut serves as a priming bed for circulating neutrophils that provoke multiple organ failure. J Trauma. 1994;37:881-7.

13. Kim FJ, Moore EE, Moore FA, Biffl WL, Fontes B, Banerjee A Reperfused gut elaborates PAF that chemoattracts and primes neutrophils. J Surg Res. 1995;58:636-40.

14. Caty MG, Guice KS, Oldham, KT, Remick DG, Kunnel SI. Evidence for tumor necrosis factor-induced pulmonary microvascular injury after intestinal ischemia-reperfusion injury. Ann Surg. 1990;212:694-700.

15. Poggetti RS, Moore FA, Moore EE, Bensard DD, Anderson BO, Banerjee A. Liver injury is a reversible neutrophil-mediated event following gut ischemia. Arch Surg. 1992;127:175-9.

16. Freischlag JA, Hanna D. Superoxide anion release (O2-) after ischemia and reperfusion. J Surg Res. 1991;50:565-8

17. Cavriani G, Oliveira-Filho RM, Trezena AG, Silva ZM, Domingos, HV, Arruda, MJCA, et al. Lung microvascular permeability and neutrophil recruitment are different regulated by nitric oxide in a rat model of intestinal ischemia reperfusion. Eur J Pharmacol. 2004;494:241-9.

18. Souza Junior A, Poggetti RS, Fontes B, Birolini D. Gut ischemia and reperfusion activates lung macrophage for TNF and $\mathrm{H}_{2} \mathrm{O}_{2}$ production. $\mathrm{J}$ Trauma. 2000;49:232-6.

19. Renzetti LM, Paciorek PM, Tannu SA, Rinaldi NC, Tocker JE, Wasserman MA, et al. Pharmacological evidence for tumor necrosis factor as a mediator of allergic inflammation in the airway. J Pharmacol Exp Ther. 1996;278:847-53.

20. Amrani Y, Krymskaya V, Maki C, Paettieri Jr RA. Mechanisms underlying TNF-alpha effects on agonist-mediated calcium homeostasis in human airway smooth muscle cells. Am J Physiol. 1997;273:10208 .

21. Anticevich SZ, Hughes JM, Black JL, Armour CL. Induction of human airway hyperresponsiveness by tumour necrosis factor-alpha. Eur J Pharmacol. 1995;284:221-5.

22. Pachter HL, Liang HG, Hofstetter SR. Liver and biliary tract trauma. In: Feliciano D V, Moore E E, Mattox K L, editors. Trauma 3rd. StamfordConnecticut: Appleton \& Lange. 1996. p. 487-523.

23. Rivkind AI, Siegel JH, Dunham CM. Patterns of organ injury in blunt hepatic trauma and their significance for management and outcome. J Trauma. 1989;29:1398-415.

24. Pringle NA. Notes on the arrest of hepatic hemorrhage due to trauma. Ann Surg. 1908;48:541-9.
25. Colletti LM, Remick DG, Burtch GD, Kunnel SL, Strieter RM, Campbell DA. Role of tumor necrosis factor-alpha in the pathophysiologic alterations after hepatic ischemia/reperfusion injury in the rat. J Clin Invest. 1990;85:1936-43.

26. Carrick JB, Martins JR O, Snider CC, Means ND, Enderson BL, Frame $\mathrm{SB}$, et al. The effect of LPS on cytokine synthesis and lung neutrophil influx after hepatic ischemia/reperfusion injury in the rat. J Surg Res. 1997;68:16-23.

27. Lucas CE, Ledgerwood AM. Prospective evaluation of hemostatic technics for liver injuries. J Trauma. 16:442-51,1976.

28. Pachter HL, Spencer FC, Hofstetter SR, Liang HG, Coppa GF. Significant trends in the treatment of hepatic trauma. Experience with 411 injuries. Ann Surg. 1992;215:492-500.

29. Hewitt G, Halliday I, McCaigue M, Campbell G, Rowlands B, Diamond T. Mortality, endotoxaemia and cytokine expression after intermittent and continuous hepatic ischaemia. Br J Surg. 1995;82:1424-6.

30. Tavares de Lima W, Silva ZL. Contractile responses of proximal and distal trachea segments isolated from rats subjected to immunological stimulation: role of connective tissue mast cells. Gen Pharmac. 1998;30:689-95.

31. Frossard N, Muller F. Epithelial modulation of tracheal smooth muscle response to antigenic stimulation. J Appl Physiol. 1986;61:1449-56.

32. Flick D, Gifford GA. Comparison of in vitro cell cytotoxic asssays for tumor necrosis factor. J Immunol Methods. 1985;68:167-79.

33. Wright PE, Carmichael LC, Bernard GR. Effect of bronchodilators on lung mechanics in the acute respiratory distress syndrome (ARDS). Chest. 1994;106:1517-23.

34. Penseti A, Pelosi P, Rossi N, Aprigliano M, Brazzi L, Fumagali, R. Respiratory mechanics and bronchodilator responsiveness in patients with the adult respiratory distress syndrome. Crit Care Med. 1993;21:7883.

35. Kips JC, Tavernier J, Pauwels RA. Tumor necrosis factor causes bronchial hyperresponsiveness in rats. Am Rev Respir Dis. 1992:145:332-36

36. Thomas PS, Yates DH, Barnes PJ. Tumor necrosis factor-alpha increases airway responsiveness and sputum neutrophilia in normal human subjects. Am J Respir Crit Care Med. 1995;152:76-80.

37. Hakonarson H, Herrick DJ, Serrano G, Grunstein MM. Mechanism of cytokine-induced modulation of beta-adrenoreceptor responsiveness in airway smooth muscle. J Clin Invest 1996;97:2593-600.

38. Pennings HJ, Kramer K, Bast A, Buurman WA, Woulters EFM. Tumor necrosis factor-alpha induces hyperreactivity in tracheal smooth muscle of the guinea-pig in vitro. Eur Respir J. 1998;12:45-9.

39. Botha AJ, Moore FA, Moore EE, Fontes B, Banerjee A, Peterson VM. Postinjury neutrophil priming and activation states: therapeutic challenges. Shock. 1995;3:157-66.

40. Koike K, Moore EE, Moore FA, Kim FJ, Carl VS, Banerjee A. Gut phospholipase A2 mediates neutrophil priming and lung injury after mesenteric ischemia-reperfusion. Am J Physiol. 1995;268(3 Pt 1):G397403

41. Koike K, Moore FA, Moore EE, Poggetti RS, Tuder RM, Banerjee A. Endotoxin after gut ischemia/reperfusion causes irreversible lung injury. J Surg Res. 1992;52:656-62. 
42. Poggetti RS. Alterações da estrutura do hepatócito na isquemia com e sem hipovolemia Estudo ultramicroscópico em ratos. Tese de Doutoramento apresentada $\$$ FMUSP , 1987.

43. Gonce ME, Brackett DJ, Squires RA, Gibson DD, Balla AK, Lerner MR, et al. Pennington LR. Development of circulatory and metabolic shock following transient portal triad occlusion. J Surg Res. 1995;59:534-43.

44. Kogure K, Suzuki M. Effects of hepatic inflow occlusion on changes in plasma potassioum, histamine and norepinefrine in rats. Circ Shock. 1992,36:290-8
45. Cunha MS, Silva JCF, Nakamoto HA, Ferreira MC. Study of warm ischemia followed by reperfusion on a lower limb model in rats: effect of allopurinol and streptokinase. Clinics. 2005;60:213-220

46. Martins O Jr, Carrick JB, Snider CC, Enderson B, Frame SB, Morris SA $\mathrm{MD}$, et al. Hepatic ischemia/reperfusion injury increases serum cytokines and lung, kidney and gut neutrophil influx. Shock. 1996;5:abstracts 1 (supplement).

47. Haddad E-B, Rousell J. Regulation of expression and function of the M2 muscarinic receptor. Trends Pharmacol Sci. 1998;19:322-7.

48. Barnes PJ, Karin M. Nuclear factor-kappaB: a pivotal transcription factor in chronic inflammatory diseases. N Engl J Med. 1997;336:1066-71. 